\title{
Learning Styles and Disciplinary Differences: A Cross-Sectional Study of Undergraduate Students
}

\author{
Ana Clara Ventura and Nora Moscoloni \\ National Research Council of Argentina (CONICET), Rosario, Argentina \\ Email: ventura@comahue-conicet.gob.ar
}

\begin{abstract}
Knowledge of learning styles can enhance the ability of teachers to build on student experiences and construct new learning opportunities. This cross-sectional study examines the learning styles preferences of undergraduate Argentinean students and the differences in their learning styles according to Field of Study and Academics Years using Index of Learning Styles ${ }^{\odot}$. The sample consisted of 304 students from Psychology and Engineering enrolled on First, Third and Fifth Years. Results suggested that students in early years at university adopted learning styles that were similar to each other irrespective of main academic discipline. However, learning styles of students in upper division courses tended to be related to the Field of Study. Engineering students were found to be more Sensing, Active and Visual learners; whereas Psychology students preferred the opposite styles. In regard to Academic Years in Psychology, Fifth Year students were more Intuitive, Reflective, Verbal and Global than First Year students. Furthermore, Engineering Fifth Year students have consolidated Sensing, Visual and Sequential styles. Besides, this group showed greater Active preferences than the Engineering First Year students. These findings confirmed the hypothesis of educational specialization based on the association between learning styles and Fields of Study; these educational implications are discussed.
\end{abstract}

Index Terms-felder-silverman learning styles model, teaching, stylistic specialization, higher education

\section{INTRODUCTION}

Students learn in different ways -by seeing and hearing, reflecting and acting, reasoning logically and intuitively, and memorizing and visualizing-. These preferences in the ways they acquire, process, and organize information into useful knowledge define learning styles (Felder, 1996; Felder \& Brent, 2005; Fry, Ketteridge \& Marshall, 2009; Subramaniam, Yong, Abdullah \& Elankovan, 2014).

As opposed to the more marked trend in research and educational practice which treats learning styles as fixed personality traits (Sternberg, Grigorenko \& Zhang, 2008), Kolb presents a different idea. Kolb and Kolb (2005) define learning style as a socio-psychological concept which is shaped by interactions between people and their

Manuscript received July 1, 2015; revised October 13, 2015. educational environment. In support of this view, Felder summarizes his position:

Learning styles are not immutable aspects of personality that people are born with and die with. I see them as preferences that may be mild, moderate, or strong, and "flexibly stable" is a good term to describe them. They shift over time and are influenced by life experiences (Felder in Cardellini, 2002, p. 66).

In this sense, the particular relations between learning styles and early training in an academic discipline could result in individuals' orientations toward learning (Boström \& Hallin, 2013; Hativa \& Birenbaum, 2000; Jones, Reichard \& Mokhtari, 2003; Kolb, 1981; Neumann, Parry \& Becher, 2002; Nulty \& Barrett, 1996). Felder and Spurlin (2005) argue that if a student with a strong preference for sensing takes well-taught course that provides guided practice in intuitive skills, the student's comfort level with abstract conceptualization might increase and the strength of his preference for sensing might decrease accordingly.

Consequently, the question is whether the students' learning style patterns of two particular academic programs of Argentina is different or not. The present study was designed to address three specific research questions as follows:

(1) What are the preferred learning styles of undergraduate Argentinean students?

(2) What are the differences between Psychology students and Engineering students in relation to learning style preference?

(3) What are the differences regarding learning style among students from Psychology and Engineering according to Academic Years?

Consequently, the aim of this study is to explore and compare the learning styles of students enrolled in Psychology and Engineering courses. It is supposed that students tend to adapt in the course of their studies to the academic discipline's specific needs or modes of thinking and learning. Hence, the above consideration leads to three hypotheses. First, there will be relatively little difference between learning styles preferred in each Field of Study in the early years of undergraduate education. Second, disciplinary groups will show significant differences between the learning styles in the last years of undergraduate education. Third, it is possible to find stylistic tendencies in each Field of Study across Academic Years. 


\section{LITERATURE REVIEW}

There are many models to measure learning styles. Coffield, Moseley, Hall and Ecclestone (2004) analyze a wide range of taxonomies on learning styles. Among 71 learning styles taxonomies, they chose 13 of them to analyze according to internal consistency, test-retest reliability, construct validity, and predictive validity. Felder-Silverman Learning Styles Model is one of these taxonomies consistent with the idea that learning styles are a dynamic state which can be shaped by a student's specific environmental demands.

\section{A. Felder-Silverman Learning Styles Model}

This model has been successfully used in Higher Education for several years (Clarke, Lesh, Trocchio \& Wolman, 2010; DuFrene, Lehman, Kellermanns \& Pearson, 2009; Franzoni \& Assar, 2009; Graf, Lin \& Kinshuk, 2008; Letele, Alexander \& Swanepoel, 2013; Patterson, 2011). The model classifies students as having preferences for one category over the other in each of the following four dimensions: Sensing-Intuitive (Perception or PT), Verbal-Visual (Processing or PS), ActiveReflective (Input or IP) and Sequential-Global (Understanding or UT).

According to Felder and Brent (2005), learning styles can be briefly described as follows:

- Sensing learners are practical, concrete and oriented towards facts and procedures;

- Intuitive learners are more conceptual, innovative and oriented towards theories and underlying meanings;

- Active learners learn by trying things out and working in groups;

- Reflective learners prefer to think things through and work alone;

- Visual learners prefer visual representations of presented material such as pictures, diagrams or flow charts;

- Verbal learners prefer written and spoken explanations;

- Sequential learners tend to be linear and orderly in their thinking and learn in small incremental steps;

- Global learners are holistic, system thinkers who learn in large leaps.

\section{B. Previous Research}

Literature review in Engineering Education indicated that most of the Engineering students are Sensing, Active, Visual and Sequential (Felder \& Brent, 2005; Felder \& Silverman, 1988; Latham, Crockett \& McLean, 2014;
Neumann, 2001). Ültanir, Ültanir and Temel (2012) reported that most of the Psychology students are Intuitive, Reflective, Verbal and Global.

Differences in the above studies indicate that social and educational exchanges that unfold in the classroom, or even in a given academic community, generate some learning styles specialization among students. Specialization is understood as the accentuation of some learning preferences, weakening some other preferences (Boström \& Hallin, 2013; Kolb, 1984; Nulty \& Barrett, 1996). In other words, the specialization hypothesis might serve as an indicator of the gradual introduction into the culture of their chosen discipline.

However, although several research on learning styles and disciplinary differences reflecting a distinction in the use of learning styles between students from different majors, the relationship between learning styles, Academic Years and students' Fields of Study are not explicit because of the coexistent conflicting results. For instance, Gholami and Bagheri (2013) suggested that, even though the groups of students belonged to the same Field of Study, they did not agree in their perceptual and personality preferences. Therefore, more studies are necessary to verify the hypothesis of stylistic specialization.

Most importantly, most of the previous research was carried out with student samples that had different cultural backgrounds than students enrolled at South American universities. In addition, little is known about Argentinean students learning styles, especially about educational specialization hypothesis. Finally, there is a current need of research reports to be conducted in Hispanic countries to analyze the generalization of the previous Western findings.

\section{METHODOLOGY}

The present empirical research is a descriptivecorrelational and cross-sectional quantitative study.

\section{A. Participants}

A total of 304 participants of Universidad Nacional de Rosario (Argentina) were involved in the study fitting into six groups: (a) 64 First Year Psychology students; (b) 52 Third Year Psychology students; (c) 43 Fifth Year Psychology students; (d) 62 First Year Engineering students; (e) 40 Third Year Engineering students; and (f) 43 Fifth Year Engineering students.

The sample consisted of $176(57.8 \%)$ females and 128 $(42.2 \%)$ males. Table I presents the study sample demographics.

TABLE I. DEMOGRAPHIC ChaRACTERISTICS OF SURVEYED STUDENTS $(\mathrm{N}=304)$

\begin{tabular}{|c|c|c|c|c|c|}
\hline \multirow{2}{*}{ Fields of Study } & \multirow{2}{*}{ Academic Year } & \multirow{2}{*}{$n$} & \multicolumn{2}{|c|}{ Gender } & \multirow{2}{*}{$\begin{array}{c}\text { Age } \\
\text { Mean } \pm \mathrm{SD}\end{array}$} \\
\hline & & & Male & Female & \\
\hline \multirow{4}{*}{$\begin{array}{l}\text { Psychology } \\
\text { (P) }\end{array}$} & First (1) & 64 & 10 & 54 & $19( \pm 1.40)$ \\
\hline & Third (3) & 52 & 4 & 48 & $24( \pm 6.81)$ \\
\hline & Fifth (5) & 43 & 8 & 35 & $25( \pm 5.82)$ \\
\hline & Total & 159 & 22 & 137 & $22( \pm 5.70)$ \\
\hline \multirow{4}{*}{$\begin{array}{l}\text { Engineering } \\
\text { (E) }\end{array}$} & First (1) & 62 & 48 & 14 & $20( \pm 1.31)$ \\
\hline & Third (3) & 40 & 30 & 10 & $22( \pm 1.68)$ \\
\hline & Fifth (5) & 43 & 28 & 15 & $23( \pm 2.08)$ \\
\hline & Total & 145 & 106 & 39 & $22( \pm 2.21)$ \\
\hline
\end{tabular}




\section{B. Instrument}

The Index of Learning Styles (ILS ${ }^{\odot}$ ), created by Felder and Soloman (1997) and based on Felder and Silverman learning styles, is a 44 item instrument designed to assess the preferences of students on four dimensions: Sensing/Intuitive, Active/Reflective, Visual/Verbal and Sequential/Global (e.g., I understand something better after I: A. try it out or B. think it through).

The ILS ${ }^{\complement}$ is a self-scoring instrument based on 11 forced-choice items for each dimension, with scores ranging from -11 to +11 in increments of $2(-11,-9, \ldots 7$, $9,11)$. The score is obtained by subtracting the number of answers related to one category from the number of answers related to the opposite category. In this way, the final results from the test are four scores, one for each dimension. For example, a score of 2 " $A$ " and 9 "B" for a participant in the Active-Reflective category, will result in a score of $7 \mathrm{~B}$, indicating that he/she is a Reflective learner.

If a student gets a score from 1 to 3 in any dimension, he/she has a mild and well balanced learning style preference. Differently, if the score is from 5 to 7 , the student has a moderate preference and he/she will learn more easily in teaching systems that favor that dimension. Finally, if the student scores from 9 to 11 , he/she could have difficulties when learning through a system that does not support this preference.

Litzinger, Ha Lee, Wise and Felder (2007) assessed the psychometric properties of the ILS ${ }^{\odot}$ and indicated that the instrument had acceptable levels of internal consistency reliability (all exceed the minimum standard of .50 suggested and preference assessments) and that evidence for its construct validity is strong.

ILS $^{\odot}$ was translated and validated by Troiano, Breitman and Gete-Alonso (2004) from English into Spanish. The present study applied the ILS $^{\odot}$ on a pilot sample of 263 students, and Kuder-Richardson 20 value was .68. According to Tuckman (1999), Felder and Spurlin (2005) suggest that a value of 0.5 or greater is acceptable for instruments that measure attitudes in general and learning styles preferences in particular.

\section{Data Analysis}

Initial application of the Kolmogorov-Smirnov test indicated that data distribution was non-normal. Descriptive statistics were applied to calculate the absolute frequencies and percentages of learning styles in the various Fields of Study. Due to the non-normality of the data set, non-parametric statistics were used in search of significant differences of preferred learning styles between groups. For this reason, median and ranges (maximum and minimum) are also presented as data aggregates.

Comparisons between Fields of Study were made using Mann Whitney $U$ test that examines whether population medians from two independent samples are equal. Thus, comparisons between academic degrees into a Fields of Study were made using the Kruskal-Wallis test that examines whether population medians from three independent samples are equal. The significance level was set at $5 \%, \mathrm{p}<.05$. The data were all analyzed using the statistical program SPSS.

\section{RESULTS}

\section{A. Descriptive Analysis}

Students were classified according to scales FelderSilverman Model by means of ILS ${ }^{\odot}$ application. Learning style profiles of six Academic Years showed that students were more Sensing $(n=203,67 \%)$, Active $(n=175$, $58 \%)$, Visual $(n=206,68 \%)$ and Sequential $(n=175$, $58 \%$ ) than Intuitive, Reflective, Verbal and Global.

\section{B. Inter-Disciplinary Differences}

Selecting only the surveyed students who were in First Year, it was observed whether any difference was evident in the learning styles of students according to their main focus of study. Non-parametric Mann-Whitney U tests (Table II) showed no significant difference between learning styles according to Fields of Study in this sample, except in Understanding $(U=1486.5, p<.05)$.

TABLE II. Descriptive Summary (DS) ABout Learning STYLE IN First, ThiRd AND Fifth YeAR By Field of Study

\begin{tabular}{|c|c|c|c|c|c|c|c|c|c|}
\hline \multirow[b]{2}{*}{ DS } & \multirow[b]{2}{*}{ Dimension } & \multicolumn{2}{|c|}{ First Year } & \multirow{2}{*}{ Dimension } & \multicolumn{2}{|c|}{ Third Year } & \multirow{2}{*}{ Dimension } & \multicolumn{2}{|c|}{ Fifth Year } \\
\hline & & $\mathrm{P}$ & $\mathbf{E}$ & & $\mathrm{P}$ & E & & $\mathrm{P}$ & $\mathbf{E}$ \\
\hline Median & & -3 & -3 & & -1 & -3 & & -1 & -5 \\
\hline Mean Score & & -2.66 & -2.58 & & -.42 & -3.50 & & -.02 & -3.51 \\
\hline$S D$ & P1 & 4.47 & 4.19 & $P 1^{2}$ & 4.27 & 4.12 & P1 & 5.57 & 4.11 \\
\hline Min & & -9 & -11 & & -7 & -9 & & -11 & -9 \\
\hline $\operatorname{Max}$ & & 7 & 7 & & 9 & 3 & & 11 & 11 \\
\hline Median & & -1 & -1 & & -1 & -1 & & -1 & -3 \\
\hline Mean Score & PS & -1 & -1.19 & DS & 1.08 & -.65 & & .63 & -3 \\
\hline$S D$ & PS & 3.49 & 4.20 & PS & 3.92 & 4.14 & 13 & 4.37 & 3.08 \\
\hline Min & & -11 & -11 & & -5 & -9 & & -7 & -11 \\
\hline $\operatorname{Max}$ & & 7 & 9 & & 11 & 7 & & 9 & 5 \\
\hline Median & & -3 & -4 & & -1 & -3 & & -1 & -5 \\
\hline Mean Score & IP & -2.44 & -3.75 & $\mathrm{JP}^{* * *}$ & -.31 & -3.95 & $\mathrm{JP}^{* * * *}$ & .58 & -5.19 \\
\hline$S D$ & 11 & 4.23 & 4.78 & 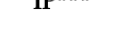 & 5.02 & 3.86 & IT & 4.56 & 3.99 \\
\hline Min & & -11 & -11 & & -11 & -11 & & -9 & -11 \\
\hline $\operatorname{Max}$ & & 7 & 7 & & 9 & 7 & & 9 & 5 \\
\hline Median & & -3 & -1 & & -1 & -1 & & -1 & -1 \\
\hline Mean Score & & -2.38 & -.55 & & .31 & -1 & & .81 & -1.19 \\
\hline$S D$ & UT $^{*}$ & 3.48 & 4.27 & UT & 4.53 & 4 & UT & 3.87 & 4.04 \\
\hline Min & & -11 & -9 & & -9 & -9 & & -7 & -9 \\
\hline $\operatorname{Max}$ & & 9 & 9 & & 11 & 7 & & 9 & 5 \\
\hline
\end{tabular}


Score distributions for the Sensing-Intuitive scale indicated increased mild Sensing preferences in each academic discipline. The analysis of the responses on the other two scales called Processing and Understanding showed similar trends about Active and Sequential styles respectively, except Input scale (Psychology $M=-2.44$, $S D=4.23$ equal to mild Sensing preference; Engineering $M=-3.75, S D=4.78$ equal to moderate Sensing preference). Thus, it confirmed the first hypothesis: students show similar learning styles in the early years of undergraduate education independently of their Field of Study.

Same analysis in Third Year showed that students adopted different types of Perception $(\mathrm{U}=666.5, \mathrm{p}<.01$ ) and Input $(\mathrm{U}=515, \mathrm{p}<.001)$ across Field of Study (Table II). In this sense, students from the three Psychology courses selected preferred more Intuitive and Verbal learning styles than Engineering courses which preferred Sensing and Visual styles.

Finally, results showed a greater variability in Fifth Year. In this case, learning styles differences in Perception $(U=555, \mathrm{p}<.001)$, Processing $(U=476, \mathrm{p}$ $<.001)$ and Input $(U=327.5, \mathrm{p}<.001)$ dimensions were found.

Regarding the level of preference in the learning styles given, it was found that preference levels in Psychology styles are low in the following: intuitive, thoughtful, verbal and global styles. Instead, Engineering students showed medium to moderate levels to the sensory and visual styles and low to mild towards the active and sequential levels.
Consequently, the second hypothesis was confirmed. In the last years of undergraduate education, disciplinary groups showed significant differences between the learning styles compared to students of early years.

Thus, we decided to pool the data from all three years of Psychology ( $n=159$ students) and Engineering ( $n=$ 145 students) for the last data analysis according to interdisciplinary comparisons. Results suggested that Perception $(U=9089, p<.001)$, Processing $(U=9162, p$ $<.001)$ and Input $(U=7224, p<.001)$ were significantly different between the two disciplinary groups.

\section{Intra-Disciplinary Differences}

In order to determine whether learning style scores differed by Academic Year, Non-parametric KruskalWallis tests (Table III) was conducted among three groups. Results indicated significant difference as follows: Perception $\left(x^{2}=10.19, p<.01\right)$, Processing $\left(x^{2}=7.53, p\right.$ $<.01)$, Input $\left(x^{2}=15.18, p<.001\right)$ and Understanding $\left(x^{2}\right.$ $=22.38, p<.001)$. Fifth Year students had significantly greater Reflective, Intuitive, Verbal and Global preference compared to first and third years.

Furthermore, results about non-parametric KruskalWallis tests indicated significant difference in one scale across the three Academic Years in Engineering: Processing $\left(x^{2}=8.28, p<.01\right)$. Fifth Year students had significantly greater Active preference regarding to First and Third years. The rest of scales showed the same preferences based on Sensing, Visual and Sequential styles with a little increase between Academic Years.

TABLE III. DESCRIPTIVE SUMMARY (DS) ABOUT LEARNING STYLE IN PSYCHOLOGY AND ENGINEERING BY ACADEMIC YEAR

\begin{tabular}{|c|c|c|c|c|c|c|c|c|}
\hline \multirow{2}{*}{ DS } & \multirow{2}{*}{ Dimension } & \multicolumn{3}{|c|}{$\mathbf{P}$} & \multirow{2}{*}{ Dimension } & \multicolumn{3}{|c|}{$\mathbf{E}$} \\
\hline & & 1 & 3 & 5 & & 1 & 3 & 5 \\
\hline Median & & -3 & -1 & -1 & & -3 & -3 & -5 \\
\hline Mean Score & & -2.66 & -.42 & -.02 & & -2.58 & -3.50 & -3.51 \\
\hline$S D$ & $P 1^{n}$ & 4.47 & 4.27 & 5.57 & PT & 4.19 & 4.12 & 4.11 \\
\hline Min & & -9 & -7 & -11 & & -11 & -9 & -9 \\
\hline $\operatorname{Max}$ & & 7 & 9 & 11 & & 7 & 3 & 11 \\
\hline Median & & -1 & -1 & -1 & & -1 & -1 & -3 \\
\hline Mean Score & & -1 & 1.08 & .63 & & -1.19 & -.65 & -3 \\
\hline$S D$ & $P S$ & 3.49 & 3.92 & 4.37 & PS ** & 4.20 & 4.14 & 3.08 \\
\hline Min & & -7 & -5 & -7 & & -11 & -9 & -11 \\
\hline $\operatorname{Max}$ & & 9 & 11 & 9 & & 9 & 7 & 5 \\
\hline Median & & -3 & -1 & -1 & & -4 & -3 & -5 \\
\hline Mean Score & & -2.44 & .31 & .58 & & -3.74 & -3.95 & -5.19 \\
\hline$S D$ & $I T^{* * *}$ & 4.23 & 5.02 & 4.56 & IP & 4.78 & 3.86 & 3.99 \\
\hline Min & & -11 & -11 & -9 & & -11 & -11 & -11 \\
\hline $\operatorname{Max}$ & & 7 & 9 & 9 & & 7 & he 7 & 5 \\
\hline Median & & -1 & -1 & -1 & & -1 & -1 & -1 \\
\hline Mean Score & & -2.38 & .31 & .81 & & -.55 & -1 & -1.19 \\
\hline$S D$ & UT & 3.48 & 4.53 & 3.87 & UT & 4.27 & 4 & 4.04 \\
\hline Min & & -11 & -9 & -7 & & -9 & -9 & -9 \\
\hline $\operatorname{Max}$ & & 9 & 11 & 9 & & 9 & 7 & 5 \\
\hline
\end{tabular}

Consequently, the third hypothesis was confirmed by the results: it is possible to find stylistic tendencies in each Field of Study by Academic Years. Stylistic tendencies prone to discontinuity (change) were found among the students of Psychology of different academic year. On the other hand, stylistic tendencies prone to continuity (stress) of the learning preferences were found among the students of Engineering as they advanced in their academic education.

In other words, these results support the conception of learning style as a dynamic interplay between individual and contextual settings. Specially, the results show that learning styles were shaped by each disciplinary specialization process. 


\section{DISSCUSSION AND CONCLUSION}

The main purpose of this paper has been to compare learning styles of Argentinean undergraduate students enrolled in Psychology and Engineering courses. The overall results in this research showed differences in learning preferences by Field of Study and Academic Years, consistent with several previous studies (Felder \& Brent, 2005; Hativa \& Birenbaum, 2000; Jones, Reichard \& Mokhtari, 2003; Kolb, 1981; Latham, Crockett \& McLean, 2014; Neumann, 2001; Neumann, Parry \& Becher, 2002; Nulty \& Barrett, 1996; Ültanir, Ültanir \& Temel, 2012).

In other words, students in the lower division courses adopt similar learning styles independently of the academic discipline; while students in the upper division courses adopt different learning styles across Field of Study, and those students reflect divergent tendencies regarding learning styles. In this sense, Psychology students increased Intuitive, Reflective, Verbal and Global learning styles across Academic Years. Furthermore, Engineering students increased Sensing, Active, Visual and Sequential preferences.

All these findings suggest that the social and educational exchanges affect students' learning styles. Thus, these findings support the approach which considers styles as preferences dynamic instead of personality fixed traits (Kolb \& Kolb, 2005; Felder \& Spurlin, 2005; Rayner, 2011; Sternberg, Grigorenko \& Zhang, 2008).

Furthermore, these findings contradict the assumption that other factors such as personal interests, abilities and background knowledge are the key for student differences regarding to learning, and contradict that learning styles are a "myth" (Dembo \& Howard, 2007; Riener \& Willingham, 2010). The present study indicates that learning styles genuinely exist and are useful to educational practices.

Teachers can provide some alternative instructions for different groups of learners. Franzoni and Assar (2009, p. 22) suggest several teaching strategies which are appropriate for different groups of learners as follows:

- Sensing: Problem-Based Learning (PBL), presentations, question and answer method;

- Intuitive: Games and simulation, role playing, discussion panel, case study and project design method;

- Active: Games and simulation, PBL, role playing, discussion panel, brainstorming and project design method;

- Reflective: Presentations, case study and question and answer method;

- Visual: Games and simulation and presentations;

- Verbal: Discussion panel, brainstorming and question and answer method;

- Sequential: Presentations and question and answer method;

- Global: Role playing, brainstorming, case study and project design method.
On the other hand, learners may benefit from the results of this study as well. By knowing their individual learning style and adapting it in accordance to the teaching methods they meet during their education, learners may also improve their performance throughout the academic programs (Evans, Cools \& Charlesworth, 2010). Nulty and Barrett (1996) report that students who adapt learning styles that relate to the discipline report more positive outcomes. Correspondingly, learners may adapt their learning preferences into the teaching methods of the programs they are studying. This information can also be used as a guide in the university entrance exam to inform candidates about the programs that are appropriate for their individual learning styles. According to Demirbas and Demirkan (2007), when the characteristics of different Fields of Study are considered, different learning styles may be more effective.

Finally, we must be careful when interpreting any of the results of this study. The results obtained have the nature of suggestions rather than conclusions or determinants. First, the number of disciplines involved is relatively small. Second, although the data supports the idea of educational specialization of learning styles in higher education students, it is necessary to replicate this study in other academic disciplines and in several countries. Third, to be more thorough, it would be necessary to conduct a longitudinal study. Last, it is not only the discourse style, methodology, course structures and epistemological concerns of a discipline that influence the learning style, but also the educational processes involved. Students' learning styles are not necessarily a consequence of the discipline per se but of the way it is taught. It is perhaps for this reason that it is necessary to investigate teaching styles in relation to learning styles into a discipline.

\section{ACKNOWLEDGEMENT}

This study could not have been conducted without the collaboration of teachers and the many students who agreed to let their ILS(C) scores serve as data for this research. This work was supported in part by a grant from National Research Council of Argentina (CONICET).

\section{REFERENCES}

[1] L. Boström and K. Hallin, "Learning style differences between nursing and teaching students in sweden: A comparative study," International Journal of Higher Education, vol. 2, no. 1, pp. 22-34, 2013.

[2] L. Cardellini, "An interview with Richard M. Felder," Journal of Science Education, vol. 3, no. 2, pp. 62-65, 2002.

[3] T. Clarke, J. Lesh, J. Trocchio, and C. Wolman, "Thinking styles: Teaching and learning styles in graduate education students," Educational Psychology: An International Journal of Experimental Educational Psychology, vol. 30, no. 7, pp. 837-848, 2010.

[4] F. Coffield, D. Moseley, E. Hall, and K. Ecclestone, Learning Styles and Pedagogy in Post-16 Learning. A Systematic and Critical Review, London: Learning and Skills Research Centre, 2004.

[5] M. Dembo and K. Howard, "Advice about the use of learning styles: A major myth in education," Journal of College Reading and Learning, vol. 37, pp. 101-109, 2007. 
[6] O. Demirbas and H. Demirkan, "Learning styles of design students and the relationship of academic performance and gender in design education," Learning and Instruction, vol. 17, pp. 345359, 2007.

[7] D. D. Frene, C. Lehman, F. Kellermanns, and R. Pearson, "Do business communication technology tools meet learner needs?" Business Communication Quarterly, vol. 72, pp. 146-162, 2009.

[8] C. Evans, E. Cools, and Z. Charlesworth, "Learning in higher education - how cognitive and learning styles matter," Teaching in Higher Education, vol. 15, no. 4, 467-478, 2010.

[9] R. Felder, "Matters of style," ASEE Prism, vol. 6, no. 4, pp. 18-23, 1996.

[10] R. Felder and B. Brent, "Understanding student differences," Journal of Engineering Education, vol. 94, no. 1, pp. 57-72, 2005.

[11] R. Felder and L. Silverman, "Learning and teaching styles in engineering education," Engineering Education, vol. 78, no. 7, pp. 674-681, 1988.

[12] R. Felder and B. Soloman. (1997). Index of Learning Style. [Online]. https://www.engr.ncsu.edu/learningstyles/ilsweb.html

[13] R. Felder and J. Spurlin, "Reliability and validity of the Index of Learning Styles ${ }^{\Theta}:$ A meta-analysis," International Journal of Engineering Education, vol. 21, no. 1, pp. 103-112, 2005.

[14] A. Franzoni and S. Assar, "Student learning styles adaptation method based on teaching strategies and electronic media," Educational Technology \& Society, vol. 12, no. 4, pp. 15-29, 2009.

[15] A Handbook for Teaching and Learning in Higher Education. Enhancing Academic Practice, New York, Routledge, 2009, pp. $8-26$.

[16] S. Gholami and M. Bagheri, "Relationship between VAK learning styles and problem solving styles regarding gender and students fields of study," Journal of Language Teaching \& Research, vol. 4 no. 4, pp. 700-706, 2013.

[17] S. Graf, T. Lin, and A. Kinshuk, "The relationship between learning styles and cognitive traits-getting additional information for improving student modeling," Computers in Human Behavior, vol. 24, pp. 122-137, 2008.

[18] N. Hativa and M. Birenbaum, "Who prefers what? Disciplinary differences in students' preferred approaches to teaching and learning styles," 209-236, 2000.

[19] C. Jones, C. Reichard, and K. Mokhtari, “Are students' learning styles discipline specific?" Community College Journal of Research and Practice, vol. 27, no. 5, pp. 363-375, 2003.

[20] D. Kolb, "Learning styles and disciplinary differences," in Modern American College, A. Chickering, Ed., San Francisco: Jossey-Bass, 1981, pp. 232-253.

[21] D. Kolb, Experiential Learning: Experience as the Source of Learning and Development, Englewood Cliffs, NJ: Prentice Hall, 1984.

[22] A. Kolb and D. Kolb, "Learning styles and learning spaces: Enhancing experiential learning in Higher Education," Academy of Management Learning \& Education, vol. 4, no. 2, pp. 193-212, 2005.

[23] A. Latham, K. Crockett, and D. McLean, "An adaptation algorithm for an intelligent natural language tutoring system," Computers \& Education, vol. 71, pp. 97-110, 2014.
[24] M. Letele, G. Alexander, and Z. Swanepoel, "Matching/mismatching of teaching and learning styles in rural learning ecologies of Lesotho: Does it enhance academic achievement," J. Hum. Ecol., vol. 41, no. 3, pp. 263-273, 2013.

[25] T. Litzinger, S. Ha Lee, J. Wise, and R. Felder, "A psychometric study of the Index of Learning Styles ${ }^{\circledR}, "$ Journal of Engineering Education, vol. 96, no. 4, pp. 309-319, 2007.

[26] R. Neumann, "Disciplinary differences and university teaching," Studies in Higher Education, vol. 26, no. 2, pp. 135-146, 2001

[27] R. Neumann, S. Parry, and T. Becher, "Teaching and learning in their disciplinary contexts: A conceptual analysis," Studies in Higher Education, vol. 27, no. 4, pp. 405-417, 2002.

[28] D. Nulty and M. Barrett, "Transitions in students' learning styles," Studies in Higher Education, vol. 21, no. 3, pp. 333-345, 1996.

[29] D. Patterson, "Impact of a multimedia laboratory manual: Investigating the influence of student learning styles on laboratory preparation and performance over one semester," Education for Chemical Engineers, vol. 6, pp. 10-30, 2011

[30] S. Rayner, "Researching style: Epistemology, paradigm shifts and research interest groups," Learning and Individual Differences, vol. 21, pp. 255-262, 2011.

[31] C. Riener and D. Willingham, "The myth of learning styles," Change, vol. 42, pp. 32-35, 2010.

[32] R. Sternberg, E. Grigorenko, and L. Zhang, "Styles of learning and thinking matter in instruction and assessment," Perspectives on Psychological Science, vol. 3, no. 6, pp. 486-506, 2008

[33] V. Subramaniam, C. Yong, H. Abdullah, and N. Elankovan, "Learning style among native Iban students based on their gender in acquiring malay as a second language," International Journal of Learning and Teaching, vol. 1, no. 1, pp. 65-70, 2014.

[34] H. Troiano, M. Breitman, and C. Gete-Alonso, "Estilos de aprendizaje que predominan entre los estudiantes universitarios," Revista de Enseñanza Universitaria, vol. 23, pp. 63-82, 2004.

[35] B. Tuckman, Conducting Educational Research, San Diego, CA: Harcourt Brace College Publishers, 1999.

[36] E. Ültanir, G. Ültanir, and G. Temel, "The examination of university students' learning styles by means of Felder-Silverman Index," Education \& Science/Egitim Ve Bilim, vol. 37, no. 163, pp. $29-42,2012$.

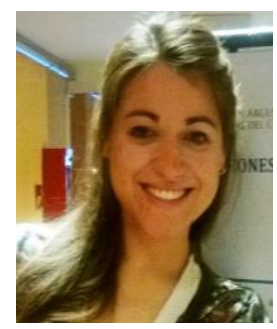

Ana Clara Ventura, PhD is a Posdoctoral Researcher in the National Research Council of Argentina. She earned her $\mathrm{PhD}$ in Psychology from University of Mar del Plata. Her research interests are Educational and Development Psychology, Learning and Teaching Styles at Higher Education, Relationships between conceptions of learning, teaching and knowledge of teachers and students from different educational levels.

Nora Moscoloni, PhD is a Principal Professional in the National Research Council of Argentina and Professor in Rosario National University. Her research interests are Methodology of the Social Science and Multidimensional Analysis. 